\title{
Effect of Diazinon, an Organophosphate Insecticide, on Plasma Lipid Constituents in Experimental Animals
}

\author{
Nagi A. Ibrahim and Basiouny A. El-Gamal* \\ Zoology Department, Faculty of Science, Zagazig University, Egypt \\ *Biochemistry Department, Faculty of Science, Alexandria University, Egypt
}

Received 12 May 2003, Accepted 16 June 2003

\begin{abstract}
There has been increasing interest in studying the various effects of organophosphate insecticides in humans and experimental animals. Only a few data are available on the effect of the organophosphate insecticide, diazinon, on lipid metabolism. The aim of this study was to evaluate the effect of diazinon on plasma lipid constituents in mammalian animals. The plasma levels of total cholesterol (TC), high-density lipoprotein cholesterol (HDL-C), lowdensity lipoprotein cholesterol (LDL-C), triglycerides (TG), and phospholipids (PL) were measured in albino rats that were orally treated with a single dose of diazinon at a level of $\mathbf{L D}_{\mathbf{5 0}}$ or with repeated daily doses at the levels of $1 / 2,1 / 8$, and $1 / 32 D_{50}$ for 2,8 , and 32 days, respectively. After a $24 \mathrm{~h}$ post-treatment with a single $\mathrm{LD}_{50}$ dose of diazinon, TC was not significantly changed, the HDL-C and PL levels were significantly decreased, but the LDL-C and TG levels were significantly increased. Separate daily oral administrations of diazinon at $1 / 2 \mathbf{L D}_{50}, 1 / 8 \mathbf{L D}_{50}$, and $1 / 32$ $\mathbf{L D}_{50}$ doses resulted in a significant decrease in HDL-C and PL, with no significant change in TG. The LDL-C levels were significantly increased and TC showed no significant change with $1 / 2 D_{50}$ and $1 / 32 L D_{50}$ doses of diazinon, whereas a significant decrease in the levels of TC, HDL-C, as well as LDL-C, was observed with the $1 / 8 \mathbf{L D}_{50}$ dose. These data suggest that diazinon may interfere with lipid metabolism in mammals.
\end{abstract}

\footnotetext{
*To whom correspondence should be addressed. Tel: 02-03-4287575

E-mail: basiouny_el_gamal@hotmail.com
}

\footnotetext{
Abbreviations: TC, total cholesterol; HDL-C, high-density lipoprotein cholesterol; LDL-C, low-density lipoprotein cholesterol; TG, triglycerides; PL, phospholipids; VLDL, very low-density lipoprotein; GOT, glutamic oxaloacetic transaminase; GPT, glutamic pyruvic transaminase; GT, glutamyltransferase; LDH, lactate dehydrogenase; FAAH, fatty acid amide hydrolase.
}

Keywords: Diazinon, Organophosphate insecticides, Plasma lipids

\section{Introduction}

There have been increasing concerns about the effects of various organophosphate insecticides in humans and experimental animals. These include cholinergic and noncholinergic biological disturbances (Dikshith et al., 1975; Davies and Holub, 1980; El-Sebae et al., 1981; McGill et al., 1981; Enan et al., 1982; Choudhari and Chakraharti, 1984; Zaher et al., 1986; Enan et al., 1987; Ansari and Kumar, 1988; Matin et al., 1990; Ali and Abdalla, 1992; Quistad et al., 2001; Bomser et al., 2002; Quistad et al., 2002; Quistad and Casida, 2002; Gordon and Mack, 2003).

Some reports have been published with respect to the organophosphate insecticide, diazinon (Dikshith et al, 1975; McGill et al., 1981; Enan et al., 1982; Ansari and Kumar, 1988; Matin et al., 1990; Quistad et al., 2001). Dikshith et al. (1975) observed mild structural and functional changes in the liver as well as in the testis of rats after a single intraperitoneal administration of diazinon. Ansari and Kumar (1988) reported that the exposure of zebrafish to diazinon for up to $168 \mathrm{~h}$ has significantly reduced DNA, RNA, and the total protein in the liver, but significantly increased the amino acid content in a dose and time-dependent response. Enan et al. (1982) showed that the oral administration of diazinon into white rats for four wk exerted a significant inhibition to four serum enzymes. These included glutamic oxaloacetic transaminase (GOT), glutamic pyruvic transaminase (GTP), glutamyltransferase (GT), and lactate dehydrogenase (LDH). This inhibition was enhanced by the addition of ascorbic acid into the diet. Matin et al. (1990) showed that the administration of diazinon into rats resulted in carbohydrate metabolism changes that were abolished by adrenalectomy, suggesting a possible involvement of the adrenals in the induced changes in 
diazinon-treated animals.

Only a few studies have been reported concerning the effect of diazinon on lipid metabolism (McGill et al, 1981; Quistad et al., 2001). McGill et al. (1981) demonstrated that feeding baboons a high saturated fat, high cholesterol diet containing a very low concentration of diazinon for 26 mo had no effect on the body weight, serum lipid, or lipoprotein cholesterol concentrations or experimental atherosclerosis. Quistad et al. (2001) showed that the intraperitoneal administration of diazinon to mice inhibited brain fatty acid amide hydrolase (FAAH), a sensitive target for organophosphate insecticides, by $50 \%$. They concluded that this induced FAAH inhibition may lead to reduced limb mobility as a secondary neurotoxic effect.

Lipids play an important role in virtually all aspects of biological processes in the body. Disturbances of its level in tissues and serum are usually associated with many abnormalities, including gallstone formation, atherosclerosis, and coronary artery disease (Moss et al., 1987).

The purpose of the present study was to evaluate the effects of diazinon on lipid constituents in the plasma of mammalian experimental animals. These included the levels of total cholesterol (TC), high-density lipoprotein cholesterol (HDLC), low-density lipoprotein cholesterol (LDL-C), triglycerides (TG), and phospholipids (PL).

\section{Materials and Methods}

Diazinon 60 EC was applied as a commercial emulsifiable concentrate formulation containing $60 \%$ active ingredient. It was diluted in deionized water for the final concentration. The acute oral $\mathrm{LD}_{50}$ for male albino rats (Sprague-Dawley) was determined according to the method of Litchfield and Wilcoxon (1949). It was found to be $128 \mathrm{mg} / \mathrm{kg}$ body weight.

Rats weighing 125-150 g were randomly allocated into eight groups (10 rats in the 1st group; 20 rats in each of the 2nd, 3rd, and 4th groups; 5 rats in the 5th group, 20 rats in each of the 6th, 7th, and 8th groups). All of the animals were supplied with food and water ad. Libitum.

Animals of the 1st group were orally administered with a single acute dose of diazinon at the level of $\mathrm{LD}_{50}$. The rats that remained alive for $24 \mathrm{~h}$. following treatment (5 rats) and the control rats of the 5 th group were sacrificed by decapitation.

Rats of the $2 \mathrm{nd}$, 3rd, and 4th groups were orally given daily doses of diazinon at the levels of $1 / 2,1 / 8$, and $1 /{ }_{32} \mathrm{LD}_{50}$ for 2,8 , and 32 $\mathrm{d}$, respectively. Animals of the 5th, 6th, 7th, and 8th groups were used as controls for the 1st, 2nd, 3rd, and 4th treated groups, respectively.

Five rats from each group of the daily treatment and controls were deprived of food overnight before the lst, 5th, 10th, and 15th d following the termination of the treatment periods of each dose level of the insecticide. At these period intervals, the rats were slightly anaesthetized with ether. Blood samples were collected in EDTA tubes through a heart puncture and immediately centrifuged at $3000 \mathrm{rpm}$ for $15 \mathrm{~min}$. Plasma was separated and kept at $-80^{\circ} \mathrm{C}$ until the biochemical analysis began.

TC was determined by the enzymatic colorimetric method of Flegg (1973). The HDL-C levels were assessed after precipitation of chylomicrons, very low-density lipoprotein (VLDL), and LDL-C by adding phosphotungestic acid and magnesium ions to the sample, also by means of an enzymatic colorimetric method (Burstein et al., 1970; Lopes-Virella et al., 1977). TG determination was carried out by the enzymatic colorimetric method of Wahlefeld (1974). PL were determined colorimetrically using the molybdate vanadate reaction according to the method of Zilversmith et al. (1950). LDL-C was calculated using the formula of Friedewald et al. (1972).

Data were statistically analyzed by Students "t" test (Hill, 1971). Differences among the groups were considered significant at $\mathrm{P}<0.05$.

\section{Results}

Table 1 presents the plasma lipid levels at $24 \mathrm{~h}$ following a single acute oral administration of diazinon at the dose level of $\mathrm{LD}_{50}$. A slight but not significant decrease of plasma TC and significant decreases of plasma HDL-C and PL were observed. Whereas, a significant elevation in plasma levels of LDL-C and TG was recorded in rats at $24 \mathrm{~h}$ after the administration of a similar dose level.

Table 2 shows that the daily administration of diazinon at the dose levels of $1 / 2,1 / 8$, and $1 / 32 \mathrm{LD}_{50}$ for 2,8 , and $32 \mathrm{~d}$, respectively, produced a general decrease in the plasma TC levels. The highest decrease value was recorded in rats that were treated with the $1 / 8 \mathrm{LD}_{50}$ dose level. Administration of the $1 / 2 L_{50}$ dose level produced a moderate but significant decrease of plasma TC at 10 and $15 \mathrm{~d}$ post treatment. There was a slight but insignificant decrease at the lst and 5th $\mathrm{d}$ of

Table 1. Plasma lipid constituents levels at $24 \mathrm{~h}$ post a single oral administration of diazinon at $\mathrm{LD}_{50}$ dose level into male albino rats

\begin{tabular}{cccccc}
\hline \multirow{2}{*}{ Treatment } & \multicolumn{3}{c}{ Plasma lipid constituents } \\
\cline { 2 - 6 } & TC & HDL-C & LDL-C & TG & PL \\
\hline Control (untreated) & $122 \pm 4$ & $69 \pm 2$ & $34 \pm 2$ & $100 \pm 5$ & $171 \pm 5$ \\
24 hours Post-treatment & $114 \pm 5^{\text {NS }}$ & $38 \pm 2^{* * *}$ & $53 \pm 3^{* * *}$ & $118 \pm 6^{*}$ & $137 \pm 7^{* *}$ \\
\% Difference & -6.6 & -45 & +56 & +18 & -20 \\
\hline
\end{tabular}

NS, Non signiftcant; $* \mathrm{P}<0.05$, ** $\mathrm{P}<0.01, * * * \mathrm{P}<0.001$.

Values expressed as $\mathrm{mg} / \mathrm{dl}$ of plasma are mean $\pm \mathrm{SE}$ of 5 separate animals in each group. $\mathrm{P}$ values $<0.05$ are considered significant. 
Table 2. Plasma TC levels at different periods of time following oral administration of selected dose levels of diazinon into male albino rats

\begin{tabular}{cccccc}
\hline & & \multicolumn{4}{c}{ post-treatment days before decapitation } \\
\cline { 3 - 6 } & & 1 & 5 & 10 & 15 \\
\hline \multirow{2}{*}{$1 / \mathrm{LD}_{50}$} & Control & $121 \pm 3$ & $122 \pm 4$ & $122 \pm 5$ & $121 \pm 4$ \\
& Treated & $116 \pm 6^{\mathrm{NS}}$ & $112 \pm 3^{\mathrm{NS}}$ & $105 \pm 5^{*}$ & $107 \pm 4^{*}$ \\
& \% Difference & -4 & -8 & -14 & -12 \\
\hline $1 / 8 \mathrm{LD}_{50}$ & Control & $121 \pm 3$ & $122 \pm 3$ & $122 \pm 5$ & $122 \pm 3$ \\
& Treated & $72 \pm 4^{* * *}$ & $77 \pm 5^{* * *}$ & $86 \pm 6^{* *}$ & $90 \pm 7^{* *}$ \\
& $\%$ Difference & -40 & -37 & -30 & -26 \\
\hline \multirow{2}{*}{$1 /{ }_{32} \mathrm{LD}_{50}$} & Control & $122 \pm 3$ & $122 \pm 2$ & $122 \pm 4$ & $122 \pm 3$ \\
& Treated & $117 \pm 5^{\mathrm{NS}}$ & $114 \pm 5^{\mathrm{NS}}$ & $113 \pm 5^{\mathrm{NS}}$ & $116 \pm 4^{\mathrm{NS}}$ \\
& $\%$ Difference & -4 & -7 & -7 & -5 \\
\hline
\end{tabular}

NS, Non signiftcant; $* \mathrm{P}<0.05, * * \mathrm{P}<0.01, * * * \mathrm{P}<0.001$.

Values expressed as $\mathrm{mg} / \mathrm{dl}$ of plasma are mean $\pm \mathrm{SE}$ of 5 separate animals in each group. $\mathrm{P}$ values $<0.05$ are considered significant.

Table 3. Plasma HDL-C levels at different periods of time following oral administration of selected dose levels of diazinon into male albino rats

\begin{tabular}{|c|c|c|c|c|c|}
\hline \multicolumn{2}{|c|}{ Dose level } & \multicolumn{4}{|c|}{ post-treatment days before decapitation } \\
\hline & & 1 & 5 & 10 & 15 \\
\hline $1 / 2 \mathrm{LD}_{50}$ & $\begin{array}{c}\text { Control } \\
\text { Treated } \\
\text { \%Difference }\end{array}$ & $\begin{array}{l}69 \pm 1 \\
38 \pm 4 * * * \\
-45\end{array}$ & $\begin{array}{l}69 \pm 3 \\
34 \pm 2 * * * \\
\quad-51\end{array}$ & $\begin{array}{l}69 \pm 1 \\
36 \pm 2 * * * \\
-48\end{array}$ & $\begin{array}{c}69 \pm 2 \\
36 \pm 3 * * * \\
-48\end{array}$ \\
\hline $1 / 8 D_{50}$ & $\begin{array}{c}\text { Control } \\
\text { Treated } \\
\text { \%Difference }\end{array}$ & $\begin{array}{l}68 \pm 3 \\
37 \pm 3 * * * \\
\quad-46\end{array}$ & $\begin{array}{l}69 \pm 2 \\
35 \pm 3 * * * \\
\quad-49\end{array}$ & $\begin{array}{l}69 \pm 3 \\
38 \pm 2 * * * \\
-45\end{array}$ & $\begin{array}{l}69 \pm 3 \\
42 \pm 5^{* *} \\
-39\end{array}$ \\
\hline${ }^{1}{ }_{32} \mathrm{LD}_{50}$ & $\begin{array}{c}\text { Control } \\
\text { Treated } \\
\text { \%Difference }\end{array}$ & $\begin{array}{c}69 \pm 2 \\
53 \pm 3 * * \\
-23\end{array}$ & $\begin{array}{l}69 \pm 3 \\
43 \pm 4 * * * \\
-38\end{array}$ & $\begin{array}{c}69 \pm 3 \\
42 \pm 5^{* *} \\
-39\end{array}$ & $\begin{array}{l}69 \pm 2 \\
46 \pm 4 * * \\
-33\end{array}$ \\
\hline
\end{tabular}

$* * \mathrm{P}<0.01, * * * \mathrm{P}<0.001$.

Values expressed as $\mathrm{mg} / \mathrm{dl}$ of plasma are mean $\pm \mathrm{SE}$ of 5 separate animals in each group. $\mathrm{P}$ values $<0.05$ are considered significant.

the post treatment period. Administration of the ${ }^{1} / 32 \mathrm{LD}_{50}$ dose level produced a slight but insignificant decrease of plasma $\mathrm{TC}$ at all of the selected post treatment periods.

Table 3 demonstrates that the daily oral administration of diazinon at the dose levels of $1 / 2,1 / 8$, or $1 / 32 \mathrm{LD}_{50}$ into rats for 2 , 8 , and $32 \mathrm{~d}$, respectively, produced a general and significant reduction of the plasma HDL-C concentration. It lasted for 15 $\mathrm{d}$ after the treatment with the entire applied dose levels.

Table 4 shows that the daily oral administration of diazinon at the dose levels of $1 / 2$ and $1 / 32 \mathrm{LD}_{50}$ produced a significant and long lasting increase of plasma LDL-C. However, a significant decrease of plasma LDL-C that lasted for similar periods of time was observed in the rats that were treated with the $1 / 8$ $\mathrm{LD}_{50}$ dose level.

The data that are presented in Table 5 show that the daily oral diazinon administration at all of the applied dose levels into rats caused very slight but not significant changes in the plasma TG levels.

Table 6 shows that the oral administration of diazinon at all of the applied dose levels induced a general but dosedependent elevation of the plasma PL levels. These levels were higher and more significant in the rats that were treated with the $1 / 2 L_{50}$ dose level.

\section{Discussion}

In the present study, plasma TC was significantly decreased with the $1 / 8 L_{50}$ dose level of diazinon, but showed no significant changes with the rest of the dose levels that were used. Similar hypocholesterolaemia was previously reported in the serum of experimental animals that were treated with various insecticides, including acephate (Choudhari and Chakraharti, 1984), dichlorvos (Ryhanen et al., 1984), and cypermethrin (Shakoori et al., 1988). On the other hand, other insecticide members have been reported to produce a rise in serum TC. These included methomyl (Antal et al., 1979), ronnel (Rumsey et al., 1983), dieldrin (Shakoori et al., 1984), 
Table 4. Plasma LDL-C levels at different periods of time following oral administration of selected dose levels of diazinon into male albino rats

\begin{tabular}{|c|c|c|c|c|c|}
\hline \multicolumn{2}{|c|}{ Dose level } & \multicolumn{4}{|c|}{ post-treatment days before decapitation } \\
\hline & & 1 & 5 & 10 & 15 \\
\hline $1 / 2 \mathrm{LD}_{50}$ & $\begin{array}{c}\text { Control } \\
\text { Treated } \\
\text { \%Difference }\end{array}$ & $\begin{array}{l}33 \pm 2 \\
58 \pm 1 * * * \\
\quad+76\end{array}$ & $\begin{array}{l}33 \pm 2 \\
59 \pm 1 * * * \\
\quad+79\end{array}$ & $\begin{array}{l}33 \pm 2 \\
51 \pm 1 * * * \\
\quad+55\end{array}$ & $\begin{array}{l}33 \pm 2 \\
53 \pm 2 * * * \\
\quad+61\end{array}$ \\
\hline $1 / 8 D_{50}$ & $\begin{array}{c}\text { Control } \\
\text { Treated } \\
\text { \%Difference }\end{array}$ & $\begin{array}{l}34 \pm 2 \\
15 \pm 2 * * * \\
\quad-56\end{array}$ & $\begin{array}{l}34 \pm 2 \\
22 \pm 2^{* *} \\
\quad-35\end{array}$ & $\begin{array}{c}33 \pm 2 \\
26 \pm 2^{*} \\
\quad-21\end{array}$ & $\begin{array}{c}33 \pm 2 \\
26 \pm 2 * \\
\quad-21\end{array}$ \\
\hline${ }_{1}^{1} /{ }_{32} \mathrm{LD}_{50}$ & $\begin{array}{c}\text { Control } \\
\text { Treated } \\
\text { \%Difference }\end{array}$ & $\begin{array}{l}33 \pm 2 \\
43 \pm 2 * * \\
\quad+30\end{array}$ & $\begin{array}{l}33 \pm 2 \\
51 \pm 2 * * * \\
\quad+55\end{array}$ & $\begin{array}{l}34 \pm 1 \\
50 \pm 2 * * * \\
\quad+47\end{array}$ & $\begin{array}{l}33 \pm 2 \\
48 \pm 1 * * * \\
\quad+45\end{array}$ \\
\hline
\end{tabular}

$* \mathrm{P}<0.05, * * \mathrm{P}<0.01, * * * \mathrm{P}<0.001$

Values expressed as $\mathrm{mg} / \mathrm{dl}$ of plasma are mean $\pm \mathrm{SE}$ of 5 separate animals in each group. $\mathrm{P}$ values $<0.05$ are considered significant.

Table 5. Plasma TG levels at different periods of time following oral administration of selected dose levels of diazinon into male albino rats

\begin{tabular}{|c|c|c|c|c|c|}
\hline \multirow{2}{*}{\multicolumn{2}{|c|}{ Dose level }} & \multicolumn{4}{|c|}{ post-treatment days before decapitation } \\
\hline & & 1 & 5 & 10 & 15 \\
\hline $1 / 2 \mathrm{LD}_{50}$ & $\begin{array}{c}\text { Control } \\
\text { Treated } \\
\text { \%Difference }\end{array}$ & $\begin{array}{l}99 \pm 1 \\
101 \pm 1^{\mathrm{NS}} \\
\quad+2\end{array}$ & $\begin{array}{c}100 \pm 1 \\
100 \pm 1^{\mathrm{NS}} \\
0\end{array}$ & $\begin{array}{c}99 \pm 1 \\
101 \pm 1^{\mathrm{NS}} \\
+2\end{array}$ & $\begin{array}{c}99 \pm 1 \\
100 \pm 1^{\mathrm{NS}} \\
+1\end{array}$ \\
\hline $1 / 8 D_{50}$ & $\begin{array}{c}\text { Control } \\
\text { Treated } \\
\% \text { Difference }\end{array}$ & $\begin{array}{c}100 \pm 1 \\
100 \pm 1^{\mathrm{NS}} \\
0\end{array}$ & $\begin{array}{c}99 \pm 1 \\
100 \pm 1^{\mathrm{NS}} \\
\quad+1\end{array}$ & $\begin{array}{c}100 \pm 1 \\
100 \pm 1^{\mathrm{NS}} \\
0\end{array}$ & $\begin{array}{c}99 \pm 1 \\
101 \pm 1^{\mathrm{NS}} \\
+2\end{array}$ \\
\hline${ }_{1}^{1} /{ }_{32} \mathrm{LD}_{50}$ & $\begin{array}{c}\text { Control } \\
\text { Treated } \\
\% \text { Difference }\end{array}$ & $\begin{array}{c}99 \pm 1 \\
102 \pm 1^{\mathrm{NS}} \\
\quad+3\end{array}$ & $\begin{array}{c}99 \pm 1 \\
100 \pm 1^{\mathrm{NS}} \\
\quad+1\end{array}$ & $\begin{array}{c}99 \pm 1 \\
101 \pm 1^{\mathrm{NS}} \\
+2\end{array}$ & $\begin{array}{c}100 \pm 1 \\
100 \pm 1^{\mathrm{NS}} \\
0\end{array}$ \\
\hline
\end{tabular}

NS Non Significant.

Values expressed as $\mathrm{mg} / \mathrm{dl}$ of plasma are mean $\pm \mathrm{SE}$ of 5 separate animals in each group. $\mathrm{P}$ values $<0.05$ are considered significant.

and furadan (Gupta et al., 1986). The decrease of serum TC that was previously recorded in the acephate-treated rats was attributed to a reduction in HDL-C (Choudhari and Chakraharti, 1984). This could possibly be the case in the present study since a simultaneous decrease in plasma levels of both TC and HDL-C was recorded in the rats that were treated with a $1{ }_{8} \mathrm{LD}_{50}$ dose of diazinon. Moreover, it has been previously suggested that organophosphate may phosphorylate and inhibit the hydroxy-methylglutaryl CoA reductase, the key enzyme in cholesterol production (Ryhanen et al., 1984). Also, a decrease of serum TC could be a result of the organophosphate-induced stimulation of the LDL receptors which increase the clearance of cholesterol from circulation (Brown et al., 1981). Furthermore, esterification of plasma cholesterol is catalyzed by the enzyme lecithincholesterol acetyltransferase (LCAT). A possible diazinoninduced excessive activation of this enzyme activity could account for the present decrease of plasma TC since esterification of plasma TC enhances the lipid-carrying capacity of the lipoprotein (Stein, 1987).

HDL is mainly synthesized in the liver and intestinal cells. It plays an important role in cholesterol efflux from tissues and carries it back to the liver for removal as bile acids (Shakoori et al., 1988). It has been established that the elevated serum or plasma HDL levels are antiatherogenic (McGill et al., 1981), whereas the reduced levels are associated with an increased risk for coronary artery disease (Stein, 1987).

The data in the present study showed that the oral administration of a single dose, and all repeated dose levels, of diazinon decreased the level of plasma HDL-C. A similar decrease of HDL-C was previously recorded in the serum of acephate-treated rats (Choudhari and Chakraharti, 1984). However, an increase of serum HDL-C was observed in the rats that were treated with dichlorvos (Ryhanen et al., 1984). No effect was recorded in baboons that were fed a diet containing high-saturated fat, high-cholesterol, and very low concentrations of diazinon (McGill et al., 1981). 
Table 6. Plasma PL levels at different periods of time following oral administration of selected dose levels of diazinon into male albino rats

\begin{tabular}{|c|c|c|c|c|c|}
\hline \multirow{2}{*}{\multicolumn{2}{|c|}{ Dose level }} & \multicolumn{4}{|c|}{ post-treatment days before decapitation } \\
\hline & & 1 & 5 & 10 & 15 \\
\hline \multirow{3}{*}{${ }_{1}^{1}{ }_{2} \mathrm{LD}_{50}$} & Control & $172 \pm 2$ & $171 \pm 3$ & $171 \pm 2$ & $171 \pm 2$ \\
\hline & Treated & $130 \pm 5 * * *$ & $128 \pm 4 * * *$ & $122 \pm 3^{* * *}$ & $128 \pm 2^{* * *}$ \\
\hline & $\%$ Difference & -24 & -25 & -29 & -25 \\
\hline \multirow{3}{*}{$1 / 8 D_{50}$} & Control & $172 \pm 4$ & $172 \pm 3$ & $171 \pm 2$ & $171 \pm 3$ \\
\hline & Treated & $155 \pm 5^{*}$ & $154 \pm 4 * *$ & $153 \pm 4^{* *}$ & $159 \pm 4 *$ \\
\hline & $\%$ Difference & -10 & -11 & -11 & -7 \\
\hline \multirow{3}{*}{${ }_{1}{ }_{32} \mathrm{LD}_{50}$} & Control & $171 \pm 4$ & $171 \pm 3$ & $171 \pm 2$ & $171 \pm 5$ \\
\hline & Treated & $157 \pm 4 *$ & $154 \pm 3^{* *}$ & $153 \pm 4 * *$ & $144 \pm 5^{* *}$ \\
\hline & $\%$ Difference & -8 & -10 & -11 & -16 \\
\hline
\end{tabular}

$* \mathrm{P}<0.05, * * \mathrm{P}<0.001, * * * \mathrm{P}<0.001$.

Values expressed as $\mathrm{mg} / \mathrm{dl}$ of plasma are mean $\pm \mathrm{SE}$ of 5 separate animals in each group. $\mathrm{P}$ values $<0.05$ are considered significant.

It is well known that the esterification of free plasma cholesterol takes place in plasma HDL, where the reaction is catalyzed by the enzyme LCAT which uses HDL as a substrate (Zilva et al., 1988). Therefore, a possible diazinoninduced activation of this plasma enzyme activity could be considered for the observed HDL decrease in our study.

In the present study, oral diazinon administration showed the selective dose-dependent changes of plasma LDL-C. A significant increase was observed in the rats that were treated with a single dose at the level of $\mathrm{LD}_{50}$, and with repeated doses at the levels of $1 / 2 \mathrm{LD}_{50}$ and ${ }^{1} /{ }_{32} \mathrm{LD}_{50}$. This observed increase in LDL-C was accompanied by a decrease in HDL-C and no change in TC, which may suggest a change from HDL-C into LDL-C. In contrast, a decrease of plasma LDL-C was obtained in the rats that were treated with diazinon at the dose level of $1 / 8 D_{50}$. A decrease of serum LDL-C was previously recorded in dichlorvos-treated rats and attributed to an increase of liver LDL receptors (Ryhanen et al., 1984) that are responsible for the clearance of LDL-C from the circulation (Brown et al., 1981). However, no effect was recorded in the LDL-C levels in the baboons that were fed a diet containing high saturated fat and cholesterol with very low concentrations of diazinon (McGill et al., 1981).

In the present study, diazinon caused a slight but insignificant change in the plasma levels of TG. Previous studies demonstrated an increase of the serum TG concentrations in the experimental animals that were treated with different insecticides, including the organophosphate dichlorvos (Ryhanen et al., 1984) and carbamate furadan (Gupta et al., 1986). This elevation of serum or plasma TG has been attributed to an inhibition of the lipase enzyme activity of both the hepatic TG and plasma lipoproteins (Musliner et al., 1979; Goldberg et al., 1982). On the other hand, the decrease of serum TG that was recorded previously in the rats that were treated with the organophosphate insecticide acephate may be a reflection of the insecticideinduced reduction of this lipid fraction in all lipoproteins classes, particularly LDL. It is, therefore, possible to suggest that the present failure of diazinon to produce any significant change in plasma TG could possibly be due to the absence of an interaction of the insecticide in the previously mentioned mechanisms.

In the present work, a general decrease of plasma PL levels was recorded in the rats that were treated with all of the applied diazinon doses. A similar decrease of PL concentration was previously recorded in the serum of the rats that were treated with the organochlorine DDT (Mitijavila $e t$ $a l ., 1981)$ and the organophosphate acephate (Choudhari and Chakraharti, 1984). The reduction of serum PL following the acephate treatment has been attributed to the reduction of the serum fraction that is induced by the insecticide in all classes of lipoproteins (Choudhari and Chakraharti, 1984).

In conclusion, the data, obtained in the present study, suggest that the organophosphate, diazinon, may interfere with lipid metabolism in mammalian animals.

\section{References}

Ali, F. A. and Abdalla, M. H. (1992) Pathological changes in tests and liver of male albino rats after dermal exposure to DDVP insecticide. J. Egypt. Public Health Assoc. 67, 565-578.

Ansari, B. A. and Kumar, K. (1988) Diazinon toxicity: effect on protein and nucleic acid metabolism in the liver of zebrafish, Brachydanio rerio (Cyprinidae). Sci. Total Environ. 76, 63-68.

Antal, M., Bedo, M., Constantinovits, G., Nagy, K. and Szepvolgyi, J. (1979) Studies on the interaction of methomyl and ethanol in rats. Fd. Cosmet. Toxicol. 17, 333-338.

Bomser, J. A., Quistad, G. B. and Casida, J. E. (2002) Chlorpyrifos oxon potentiates diacylglycerol-induced extracellular signal-regulated kinase (ERK 44/42) activation, possibly by diacylglycerol lipase inhibition. Toxicol. Appl. Pharmacol. 178, 29-36.

Brown, M. S., Kovanen, P. T. and Goidstein, J. L. (1981) Regulation of plasma cholesterol by lipoprotein receptors. 
Science 212, 628-635.

Burstein, M., Scholnick, H. R. and Morfin, R. (1970) Rapid method for the isolation of lipoproteins from human serum by precipitation with polyanions. J. Lipid Res. 11, 583-595.

Choudhari, P. D. and Chakraharti, C. H. (1984) Effect of acephate (Orthene), an organophosphorus insecticide, on lipid metabolism in albino rats. Ind. J. Exp. Biol 22, 45-49.

Davies, D. B. and Holub, B. J. (1980) Comparative subacute toxicity of dietary diazinon in the male and female rat. Toxicol. Appl. Pharmacol. 54, 359-367.

Dikshith, T. S., Behari, J. R., Datta, K. K. and Mathur, A. K. (1975) Effect of diazinon in male rats. Histopathological and biochemical studies. Environ. Physiol. Biochem. 5, 239-299.

El-Sebae, A. H., Enan, E. E., Soliman, S. A., El-Fiki, S. and Khamees, E. (1981) Biochemical effects of some organophosphorus insecticide on new targets in white rats. $J$. Environ. Sci. Health B 16, 475-491.

Enan, E., Berberian, I. G., el-Fiki, S., El-Masry, M. and Enan O. H. (1987) Effects of two organophosphorus insecticides on some biochemical constituents in the nervous system and liver of rabbits. J. Environ. Sci. Health B 22, 149-170.

Enan, E. E., El-Sebae, A. H., Enan, O. H. and El-Fiki, S. (1982) In-vivo interaction of some organophosphorus insecticides with different biochemical targets in white rats. J. Environ. Sci. Health $B$ 17, 549-570.

Flegg, H. M. (1973) An investigation of the determination of serum cholesterol by an enzymatic method. Ann. Clin. Biochem. 10, 79-84.

Friedewald, W. T., Levy, R. I. and Fredickson, D. S. (1972) Estimation of the concentration of low density lipoprotein cholesterol in plasma without use of the preparative ultracentrifuge. Clin. Chem. 18, 499-502.

Goldberg, I. J., Paterniti, J. R., Ginsberg, H. N., Lindgren, F. T. and Brown, W. V. (1982) Lipoprotein metabolism during acute inhibition of hepatic triglyceride lipase in the Cynomolgus monkey. J. Clin. Invest. 70, 1184-1192.

Gordon, C. J. and Mack, C. M. (2003) Influence of gender on thermoregulation and cholinesterase inhibition in the long-evans rat exposed to diazinon. J. Toxicol. Environ. Health A 66, 291304.

Gupta, M., Mukherjee, S., Gupta, S. D., Dolui, A. K., Dey, S. N. and Roy, D. K. (1986) Changes of lipid spectrum in different tissues of furadan- treated mice. Toxicol. 38, 69-79.

Hill, A. B. (1971) Principles of Medical Statistics. 9th ed., Oxford Univ. Press, Oxford, UK.

Litchfield, J. T. and Wilcoxon, F. A. (1949) Simplified method of evaluating dose effect experiments. J. Pharmacol. Exp. Therap. 96, 99-113.

Lopes-Virella, M. F., Stone, P. G., Ellis, S. and Colwell, I. A. (1977) Cholesterol determination in high density lipoproteins separated by three different methods. Clin. Chem. 23, 882-884.

Matin, M. A., Husain, K. and Khan, S. N. (1990) Modification of diazinon-induced changes in carbohydrate metabolism by adrenalectomy in rats. Biochem. Pharmacol. 39, 1781-1786.

McGill, H. C. Jr., McMahan, C. A., Kruski, A. W. and Mott, G. E. (1981) Relationship of lipoprotein cholesterol concentrations to experimental atherosclerosis in baboons. Arteriosclerosis $\mathbf{1}$, 3-12.

Mitijavila, S., Carrea, G., Boigegrain, R. A. and Derache, R. (1981) Evaluation of the toxic risk of DDT in rat during accumulation. Arch. Environ. Contam. Toxicol. 10, 459-469.

Moss, D. W., Henderson, A. P. and Kachmar, J. F. (1987) Enzymes; in Fundamentals of Clinical Chemistry, Tietz, N. W. (ed.), 3rd ed. WB Saunders Company. Philadelphia, USA.

Musliner, T. A., Herbert, P. N. and Kingston, M. J. (1979) Lipoprotein substrates of lipoprotein lipase and hepatic triacylglycerol lipase from human post heparin plasma. Biochem. Biophys. Acta 575, 277-288.

Quistad, G. B. and Casida, J. E. (2002) Sensitivity of bloodclotting factors and digestive enzymes to inhibition by organophosphorus pesticides. J. Biochem. Mol. Toxicol. 14, 5156.

Quistad, G. B., Sparks, S. E. and Casida, J. E. (2001) Fatty acid amide hydrolase inhibition by neurotoxic organophosphorus pesticides. Toxicol. Appl. Pharmacol. 173, 48-55.

Quistad, G. B., Sparks, S. E., Segall, Y., Nomura, D. K. and Casida, J. E. (2002) Selective inhibitors of fatty acid amide hydrolase relative to neuropathy target esterase and acetylcholinesterase: toxicological implications. Toxicol. Appl. Pharmacol. 179, 57-63.

Rumsey, T. S., Bitman, J. and Tao, H. (1983) Changes in plasma concentrations of thyroxine, triiodothyronine, cholesterol and total lipids in beef steers fed ronnel. J. Anim. Sci. 56, 125-131.

Ryhanen, R., Herranen, J., Karhonen, K., Penttila, I., Popvilanpi, M. and Puhakainen, E. (1984) Relationship between serum lipids, lipoproteins and pseudocholinesterase during organophosphate poisoning in rabbits. Int. J. Biochem. 16, 687690.

Shakoori, A. R., Ali, S. S. and Saleem, M. A. (1988) Effects of six months feeding of cypermethrin on the blood and liver of albino rats. J. Biochem. Toxicol. 3, 59-72.

Shakoori, A. R., Rasul, Y. G. and Ali, S. S. (1984) The effect of long term administration of dieldrin on biochemical components in blood serum of albino rats. Folia Biol. 32, 213222.

Stein, E. A. (1987) Lipids, lipoproteins and apolipoproteins; in Fundamentals of Clinical Chemistry, Tietz, N. W. (ed.), 3rd ed., W. B. Saunders Company. Philadelphia, USA.

Wahlefeld, A. W. (1974) Triglycerides determination after enzymatic hydrolysis; in Methods of Enzymatic Analysis, Nergmeyer, H. V. (ed.), vol. 4, pp. 18-31, Academic Press, New York, USA.

Zaher, A. M., Fouad, A. A., Mohamed, A. A. S. and Samir, A. I. (1986) Changes in rat metabolism after simultaneous inhalation of carbamate and of insecticides. Egypt. J. Food Sci. 14, 39- 48.

Zilva, J. F., Pannall, P. R. and Mayne, P. D. (1988) Clinical Chemistry in Diagnosis and Treatment, Arnold, E. (ed.), 5th ed., Hodder and Stoughton Limited, London, UK.

Zilversmith, D. B., Davis, K. and Cols, Y. (1950) Microdetermination of plasma phospholipids by trichloroacetic acid precipitation. J. Lab. Clin. Med. 35, 155-160. 